\title{
A Summary of Some Microbes Identified from Different Indian Caves and Their Possible Role in Mineral Formations
}

\author{
Sushmitha Baskar', Ramanathan Baskar ${ }^{2 *}$ \\ ${ }^{1}$ Environmental Studies, School of Agriculture, Indira \\ Gandhi National Open University (IGNOU), \\ Maidan Garhi, New Delhi 110o68, India \\ ${ }^{2}$ Department of Environmental Science and \\ Engineering, Guru Jambheshwar University of \\ Science and Technology, Hisar 125001, Haryana, \\ India
}

Key words: Geomicrobiology, Speleothems, Biominerals

\section{Abstract}

Microbe-mineral interactions in caves can lead to secondary mineral formations such as speleothems, moonmilk etc. In the present review, we provide a summary of geomicrobiological work done so far in some Indian caves. Microbially induced mineralization is documented in cave ecosystems and microbial metabolisms help in mineral formations either through direct/active or indirect/passive processes. Laboratory based experiments conducted on speleothems from Sahastradhara caves (Dehradun); Borra Cave (Andhra Pradesh); Krem Phyllut, Krem Mawsmai, Krem Mawmluh and Rongai Dobhakol (Meghalaya) have clearly demonstrated that bacterial strains isolated from these caves have the capability to precipitate minerals under controlled conditions.

\section{Introduction}

It is well established that the earth's subsurface contains a signif icant fraction of microbial life (Roussel et al., 2008). Of these, the caves are prominent features of karst terrains that host a wide spectrum of interesting life forms: microorganisms (bacteria, fungi); cave flora (lichens, algae, mosses); cave fauna (mainly- snails, worms, spiders, leeches, insects, millipedes, centipedes, scorpions, fishes, salamanders and bats). Cave geomicrobiology is concerned with the diversity of microorganisms and their interactions with minerals, which can provide us clues on past/ongoing geomicrobiological interactions. Cave environments are usually resource limited and are extreme environments for life. Cave ecosystems also

*Corresponding Author: rbaskargjuhisar@yahoo.com 
depend on allochthonous organic matter for metabolism (Poulson \& Lavoie, 2000; Simon et al., 2003; Engel et al., 2003, 2004; Biswas, 2009; Biswas \& Ramteke, 2008; Baskar et al., 2009, 2012, 2011, 2014).

The first reports on microbial inclusions within rocks to speculate the possible role of microorganisms in carbonates was conducted five decades ago (Shoji \& Folk, 1964). Thereafter, a number of cave geomicrobiological studies have been reported world over (Melim et al., 2001; Boston et al., 2001; Hammes \& Verstraete, 2002; Frisia et al., 2002; Engel et al., 2003, 2004; Cacchio et al., 2004; Barton et al., 2004; Canaveras et al., 2006; Meisinger et al., 2007; Engel et al., 2010, 2013; Baskar et al., 2005, 2006, 2009a, 2012, 2014). Reviews on cave geomicrobiology have been published (Northup \& Lavoie, 2001; Northup et al., 1997; Barton \& Northup, 2007; Barton 2006; Ehrlich 1998; Banfield et al., 1998; Jones 2001; Newman \& Banfield, 2002; Barton \& Jurado, 2007, Whitman et al., 1998; Baskar et al., 2009b, c). Microorganisms by way of their metabolic interactions with rocks and minerals for their energy requirement play an important role in reshaping the mineral environment of caves and contribute signif icantly to various cave deposits, speleothems. Several lab based studies have clearly demonstrated that these bacterial species isolated from caves are capable of precipitating minerals under controlled conditions (Danielli \& Edington, 1983; Rivadeneyra et al., 1993; Baskar et al., 2006, 2009, 2011, 2014).

More than 1545 cave sites (Deshmukh, 1994) have been reported on the Indian subcontinent. Unfortunately, till date very little efforts have been made to understand these poor biospheres. Most of the works were restricted to understand the animal biodiversity (Biswas, 2010, Harries et al., 2008). In this short communication, a summary of the geomicrobiological work done so far by our team has been discussed to understand cave mineral-microbe interactions in some of the Indian caves.

\section{Sahastradhara caves; Uttaranchal:}

The cave systems at Sahastradhara, are situated in the Dehradun Valley, formed within the Siwalik formations in Garhwal Himalaya, situated on the Krol carbonates. These caves are smaller in size (10 $\mathrm{m}$ long, 2 m wide), and are well known for their $\mathrm{pH}$ neutral springs believed to cure skin diseases. In the studied speleothems, calcite was the dominant mineral consisting of microcrystalline calcite attributable to mineralized bacterial cells. Microbial cell enumeration by DNA-specific DAPI staining (Amann et al., 1995) revealed high

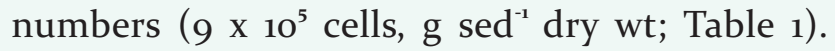
Further, in vitro culture experiments with Bacillus

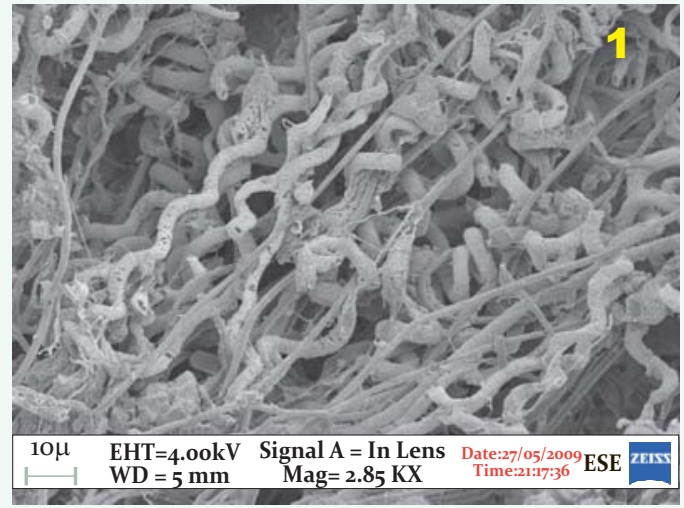

Fig. 1; SEM of Sahastradhara moonmilk showing spiral, tubular filaments; calcite formed in close association with microbial filaments . thuringiensis and Bacillus pumilis (using $16 \mathrm{~S}$ rRNA gene amplification and sequencing) strains isolated from the stalactites showed their capability to form crystalline $\mathrm{CaCO}_{3}$ 
crystals (Baskar et al., 2006). Further, moonmilk from Sahastradhara also showed bacterial involvement in their formation (Baskar et al., 2014; Fig. 1). Bacterial species identified from moonmilk that initiated crystal precipitation were: Bacillus pumilis, Bacillus cereus, Bacillus anthracis, Bacillus lentus, Bacillus circulans, Bacillus sphaericus, Actinomycetes (Table 1).

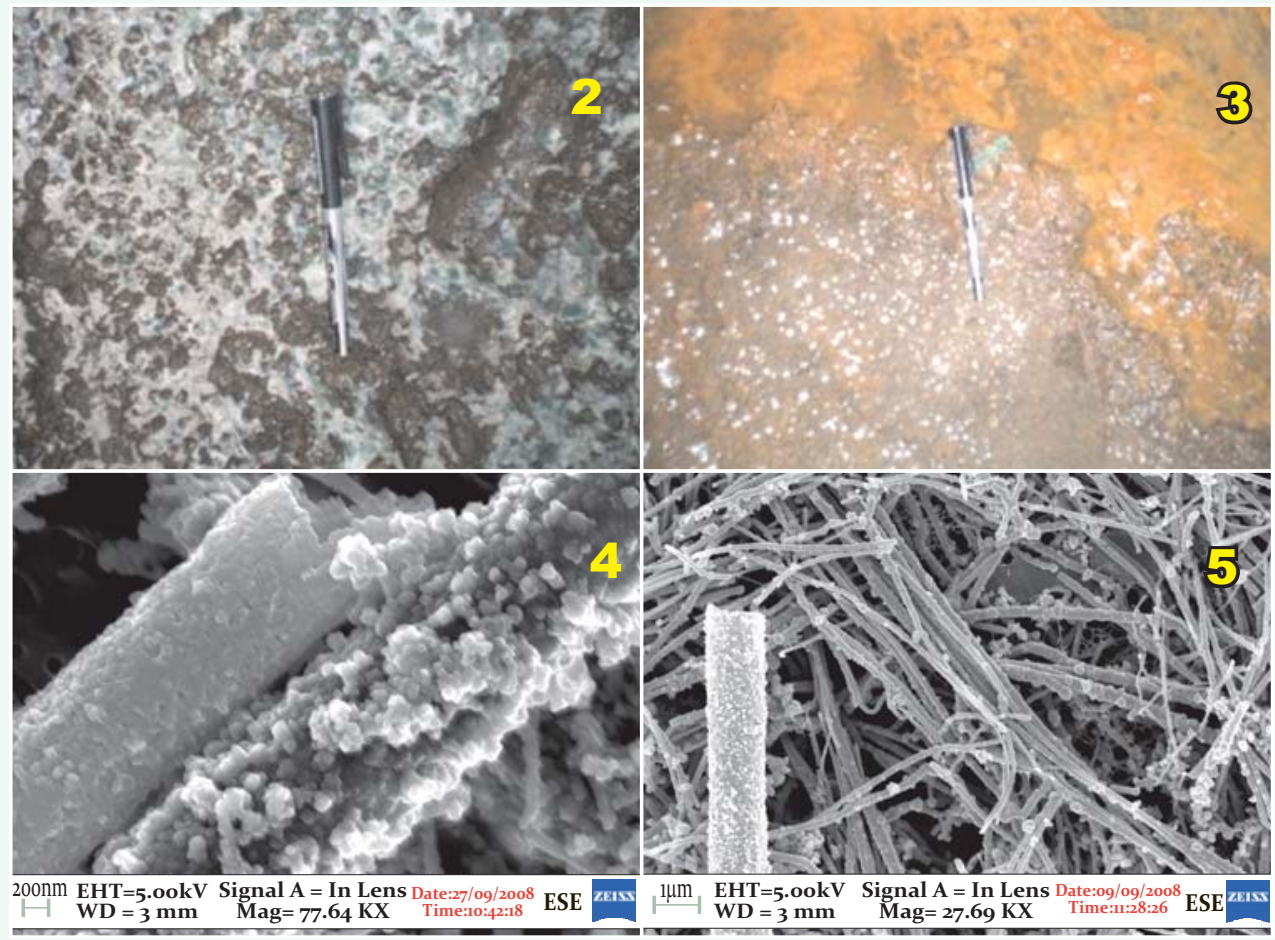

Fig.- 2: Whitish green cave wall deposits, Borra Cave, Andhra Pradesh. Fig. 3: Iron biof ilm on a neutrophilic spring, Borra cave, Andhra Pradesh. Fig 4: SEM showing sheaths of Leptothrix sp. with Fe minerals deposited on the sheaths. Fig. 5: SEM showing EPS (exopolysaccharides), long fibres and sheaths of Leptothrix sp. with Fe minerals

Borra Caves; Andhra Pradesh:

They are situated in the Araku Valley, $95 \mathrm{~km}$ from Visakhapatnam $\left(18^{\circ} 15^{\prime} \mathrm{N} ; 83^{\circ} 3^{\prime} \mathrm{E}\right)$ on the east coast of India (Bas et al., 2002). The cave is $2 \mathrm{~km}$ long, $12 \mathrm{~m}$ high and located 1,300 $\mathrm{m}$ above sea level. The cave hosts a variety of stalactites, stalagmites, cave wall formations (Fig. 2) and springs with thick biof ilms (Baskar et al., 2012; Fig. 3). SEM of speleothems revealed the presence of calcified prokaryotic-like cells, micro-rods, and needle calcite. The textures preserved in the speleothems indicate the presence of microbes and their possible role in speleogenesis. DNA sequencing analyses and electron microscopy of an Fe-rich organic mat associated with a neutrophilic spring confirmed high abundances of Leptothrix-like sheaths, poorly crystalline Fe-precipitates, a large number of hollow tubes and broken dissociated sheaths embedded in extracellular polymeric substances (EPS) (Fig. 4,5). The DNA sequencing analyses of the $16 \mathrm{~S}$ rRNA gene diversity revealed bacteria assigned to eight different phyla: Proteobacteria (62\%), Chloroflexi (8\%), Bacteroidetes (7\%), 
Planctomycetes (1\%), Actinobacteria (5\%), Acidobacteria (6\%), Nitrospira (1\%) and Firmicutes (5\%). The dominant class was the Betaproteobacteria that accounted for $28 \%$ of the sequences. Further, sequences affiliated with Leptothrix, Siderooxidans, Crenothrix, Comamonadaceae, Dechloromonas were also present (Baskar et al., 2012). Our SEM images suggest that the samples consist of amorphous to poorly crystalline siliceous Fe oxyhydroxide (Fig. 4,5,6) with characteristics similar to ferrihydrite which are in

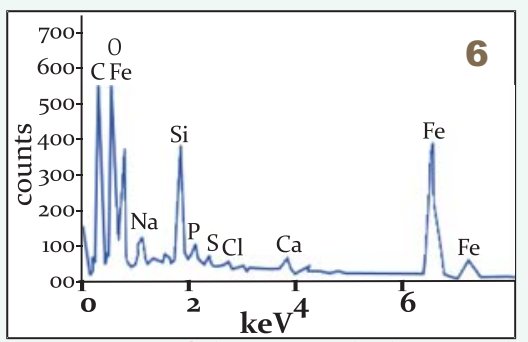

Fig. 6: EDX of the minerals deposited on the sheaths showing Fe peaks accordance with observations by several previous studies (e.g., Banfield etal. 20oo; Barton et al., 2007). Our results allow us to infer a possible relationship between the microbial community diversity to the microbial sheaths, EPS, and the iron precipitates formed.

\section{Krem Mawsmai, Krem Phyllut, Krem Mawmluh; Meghalaya:}

These caves are situated in the Khasi Hills, an uplifted Precambrian crystalline complex forming the northeastern extension of the Indian Peninsular Shield. Meghalaya has huge deposits of limestone and abundant rainfall, which is the main reason for the Karst cave formations. The important limestone deposits are in Cherrapunji located in the MawmluhMawsmai Hills. Krem Mawsmai caves are located amidst a thickly forested zone and are 160 $\mathrm{m}$ long, $15 \mathrm{~m}$ high, width $410 \mathrm{~m}$. Krem Phyllut has a large section of fossil passage, was relatively long with a total length of $1,003 \mathrm{~m}$, width $4.5 \mathrm{~m}$, height $15 \mathrm{~m}$ and had three entrances. Krem Mawmluh (Mawkhyrdop) is located near Sohra $58 \mathrm{~km}$ from Shillong, It has a "Bat Hall" which leads toa passageway full of mollusc fossils. This main passage continues toa width of $28 \mathrm{~m}$ and $25 \mathrm{~m}$ height at one place called the "Feet Up Double Doughnut Passage" leading to the big "Gold Fish Pond" (Kharpran Dally, 2006). The floor in the passageway above the Gold Fish Pond is full of sinkholes resembling Swiss cheese, and numerous moonmilk deposits occur in this part of the cave spread over $300 \mathrm{~m}$. The cell enumeration in the three caves showed good numbers in different enrichment agars tested (Table 1). The bacteria that were capable of forming calcite in vitro include: Bacillus licheniformis Bacillus cereus Bacillus pumilis Bacillus mycoides Micrococcus luteus, Streptomyces, Bacillus spp (Baskar et al., 2009a, 2011). These results are comparable to other moonmilk and speleothem culture studies (Mulec et al., 2002; Curry et al., 2009). The fossil filaments and textures observed in our study contain excess carbon, which indicate an organic composition which is in accordance with results obtained by Melim et al., (2009).

\section{Rongai Dobhakol Cave; Meghalaya:}

It is in the Garo Hills which form a western part of the Meghalaya Plateau where the area, lying to the south of the Tura Ranges, represents an extension of the Assam shelf and is characterized by thick Cenozoic deposits (Srivastava et al., 20o8). Rongai Dobhakol is situated in a dense forest in the Balpakram National park region which is a karst area in Eocene Siju (Upper Sylhet) limestone and lies at a distance of $167 \mathrm{~km}$ along the road from 
Tura. There is a plethora of speleothems and some splendid irregular shaped stalactites and stalagmites. The total population densities on nutrient agar was $4.2 \times 10^{5}$ (cells, g sed-1 dry wt; Table-1)and most isolates were aerobic rod-shaped bacteria, of which 50\% were Gram positive. Detailed experiments of pathways associated with microbial oxidation, hydrolysis, dissimilatory sulphate reduction that lead to mineral formation is presently being carried out with isolated strains in vitro.

\section{Conclusion:}

This short review summarizes the studies performed by our group on the Indian caves to understand microbe-mineral interactions. The studies have primarily focussed on geochemical, mineralogical, conventional and molecular microbiological approaches to understand the extent of microbial involvement in cave formations. In all of these caves, it has been clearly established that microbes through their metabolic functions for their energy requirement, reshape the mineral environment of caves. Minerals precipitate onto bacterial cell surfaces either through direct/enzymatic processes (biologically controlled mineralization) or indirect/passive processes (biologically induced mineralization) (Konhauser, 1998; Northup \& Lavoie, 2001). Our in vitro studies establish that passive processes i.e. biochemical factors affected by bacterial metabolism influence the precipitation process and also the shape and morphology of the carbonate precipitates attached to the mineral surface. Further, metagenomic studies along with lab based microbe-mineral experiments will help to understand mineral-microbe interactions. Thus, cave environments, offer invaluable scientific information about biosignatures detected, which can beapplied to search for subsurface life in other planets (Boston et al.,20oo).

\section{Acknowledgements:}

We thank ETH, Zurich, Switzerland; Centre for Geobiology, University of Bergen, Norway and Stockholm University, Sweden for generous laboratory facilities. RB thanks UGC for financial assistance (UGC-MRP).

\section{References:}

Amann R.I., Ludwig W. \& Schleifer K.H. (1995):. Phylogenetic identification and in situ detection of individual microbial cells without cultivation. Microbiol. Rev. 59:143-169.

Banf ield J.F., Welch S.A. \& Edwards K.J. (1998): Microbes as geochemical agents. The geochemical news, 96: 11-17.

Banfield J.F., Welch S.A., Zhang H., Ebert T.T. \& Penn R.L. (200o): Aggregation-based crystal growth and microstructure development in natural iron oxyhydroxide biomineralization products. Science, 289:75-1754.

Barton H.A. (2006): Introduction to cave microbiology: A review for the non-specialist. J. Cave Karst Stud., 68, 4354 .

Barton H.A.. \& Jurado V. (2007): What's up down there? Microbial diversity in caves. Microbe, 2:132-138.

Barton H.A..\& Northup D.E.. (2007): Geomicrobiology in cave environments: past, current and future perspectives: J. Cave KarstStud., 69(1):163-178.

Barton H.A., Taylor M.R.; Kreate M.P., Springer A.C., Oehrle S.A. \& Bertog J.L. (2007): The impact of host rock geochemistry on bacterial community structure in oligotrophic cave environments. Intl JSpeleol .36:93-104.

Barton H.A., Taylor M.R. \& Pace N.R. (2004): Molecular phylogenetic analysis of a bacterial community in an oligotrophic cave environment: Geomicrobiol.J., 21:11-20.

Bas M.J.L., Subbarao K.V.. \& Walsh J.N.. (2002): Metacarbonatite or marble? the case of the carbonate, pyroxenite, 
calcite apatite rock complex at Borra, Eastern Ghats, India.J. Asian Earth Sci., 20:127-140.

Baskar S., Baskar R.; Mauclaire L. \& McKenzie J.A. (2005): Role of microbial community in stalctite formation, Sahastradhara caves, Dehradun, India.Curr. Sci. India, 88, 1305-1308

Baskar S., Baskar R., Mauclaire L. \& McKenzie J.A. (2006): Microbially induced calcite precipitation in culture experiments:possible origin for stalactites in Sahastradhara caves, Dehradun, India. Curr. Sci. India, 90, 58-64.

Baskar S., Baskar R., Lee N., Kaushik A. \& Theophilus P.K. (2008): Precipitation of iron in the microbial mats of the spring waters of Borra Caves, Vishakapatnam, India: Some geomicrobiological aspects. Environmental Geology, Springer Publication, Vol. 56, No.2 237-243.

Baskar S., Baskar R., Lee N. \& Theophilus P.K. (2009a): Speleothem formations of Mawsmai caves and Krem Phyllut caves, Meghalaya, India: Some evidences for biogenic activities. In: Environmental Earth Science (Springer Publication), Volume 57, Number 5, 1169-1186.

Baskar S. \& Baskar R. (2009b). Geobiology and Geomicrobiology: Importance and need for studies in the Indian context, Curr. Sci. India, 96(1):200-201.

Baskar S., Baskar R. \& Barton H.A. (2009c): Cave Geomicrobiology as a thrust area of research in the Indian context. Curr. Sci. India, 97(5): 621-622.

Baskar S., Baskar R. \& Routh J. (2011): Biogenic Evidences of Moonmilk deposits in the Krem Mawmluh Cave, Meghalaya, India. Geomicrobiol.J., 28(3):252-265.

Baskar S., Baskar R., Thorseth I.H., Øvreas L. \& Pedersen R.B. (2012): Microbial iron precipitation associated with a neutrophilic spring of Borra caves, Vishakapatanam, India. Astrobiology Journal, 12 (4):327-346.

Baskar S., Baskar R. \& Routh J. (2014): Speleothems from Sahastradhara caves in Siwalik Himalaya, India: Possible biogenic inputs. Geomicrobiol.I., 31(8):664-681.

Biswas J. (2009): The biodiversity of Krem Mawkhyrdop of Meghalaya, India, on the verge of extinction. $\underline{\text { Curr. Sci. }}$ India, 96:904-910.

Biswas J. (2010): Kotumsar cave biodiversity: a review of cavernicoles and their troglophilic traits. Biodivers. Conserv. $19(1): 279-285$.

Biswas J. \& Ramteke A.K. (2008): Timed feeding synchronizes circadian rhythm in vertical swimming activity in cave loach, Nemacheilus evezardi. Biol. Rhythm Res., 39 (5), 405-412.

Boston P.J., Spilde M.N., Northup D.E., Melim L.A., Soroka D.S., Kleina L.G., Lavoie K.H., Hose L.D., Mallory L.M., Dahm C.N., Crossey L.J. \& Schelble R.T. (2001): Cave biosignature suites: Microbes, minerals and Mars. Astrobiology, 1(1):25-55.

Boston P.J., Soroka D.S., Kleina L.G., Lavoie K.H., Spilde M.N., Northup D.E. \& Hose L.D. (200o): A garden inside out: microbial mats in springs, wall muds, and ceiling formations of a sulfur-dominated cave, Cueva de Villa Luz, Tabasco, Mexico. J. Cave Karst Stud., 62(3):198199.

Cacchio P., Contento R., Ercole C., Cappuccio G., Martinez M.P. \& Lepidi A. (2004): Involvement of microorganisms in the formation of carbonate speleothems in the Cervo Cave (L'Aquila - Italy). Geomicrobiol. L., 21: 497-509.

Canaveras J.C., Cuezva S., Sanchez-Moral S., Lario J., Laiz L., Gonzalez J.M. \& Saiz-Jimenez C. (2006): On the origin of fiber calcite crystals in moonmilk deposits. Naturwissenschaften, 93:27-32.

Curry M.D., Boston P.J., Spilde M.N., Baichtal J.F. \& Campbell A.R. (2009): Cottonballs, a unique subaqeous moonmilk, and abundant subaerial moonmilk in Cataract Cave, Tongass National Forest, Alaska. Inter I Speleol, 38(2):111-128.

Danielli H.M.C. \& Edington M.A. (1983):. Bacterial calcification in limestone caves. Geomicrobiol.J., 3: 116.

Deshmukh M. (1994): Influence of geology on the localization of ancient caves.J. Geol. Soc. India, 44:213-217.

Ehrlich H.L. (1998): Geomicrobiology: its significance for geology Earth-Science Reviews, 45: 45-60.

Engel S.E., Lee N., Porter M.L., Stern A.L., Bennett P.C. \& Wagner M. (2003): Filamentous Epsilonproteobacteria dominate microbial mats from sulf idic cave springs. Appl Environ Microbiol., 69:5503.

Engel A.S., Porter M.L., Stern L.A.Quinlan S. \& Bennett P.C. (2004): Bacterial diversity and ecosystem function of 
filamentous microbial mats from aphotic (cave) sulfidic springs dominated by chemolithoautotrophic "Epsilonproteobacteria". FEMS Microbiol Ecol., 51, 31-53

Engel A.S., Meisinger D.B., Porter M.L., Payn R.A., Schmid M., Schleifer K.H. \& Lee N.M. (2010): Linking Phylogenetic and Functional Diversity to Nutrient Spiralling in Microbial Mats from Lower Kane Cave (USA). The ISME Journal, 4: 98-110.

Engel A.S., Paoletti M.G., Beggio M., Dorigo L., Pamio A., Gomero T., Furlan C., Brilli M., Bertoni R., Dreon A.L. \& Squartini A. (2013): Comparative microbial community composition from secondary carbonate (moonmilk) deposits: implications for the Cansiliella servadeii cave hygropetric food web. Int JSpeleol., 42 (3): 181-92.

Frisia S., Borsato A., Fairchild I.J., McDermott F. \& Selmo E.M. (2002): Aragonite-calcite relationships in speleothems (Grotte De Clamouse, France): Environment, fabrics and carbonate geochemistry. J. Sediment. Res., 72: 687 $=699$.

Hammes F. \& Verstraete W. (2002): Key roles of $\mathrm{pH}$ and calcium metabolism in microbial carbonate precipitation. Reviews in Environment. Sci. Biotechnol., 1:3-7.

Harries D.B., Ware F.J., Fisher C.W., Biswas J. \& Kharpran-Daly B.D. (2008): A review of the biospeleology of Meghalaya, India. J. Cave Karst Stud., 70:163-176.

Jones B. (2001): Microbial activity in Caves - A Geological Perspective. Geomicrobiol. J. , 18:345-357.

Kharpran-Dally B.D. (2006): The Caves of Meghalaya. Published by the Directorate of information and public relations. Government of Meghalaya pp. 90.

Konhauser K.O. (1998): Diversity of bacterial iron mineralization. Earth Sci Rev, 43: 91-121.

Meisinger D.B., Zimmermann J., Ludwig W., Schleifer K.H., Wanner G. Schmid M., Bennett P.C., Engel A.S.\& Lee N.M. (2007): In situ detection of novel Acidobacteria in microbial mats from a chemolithoautotrophicallybased cave system (Lower Kane Cave, WY, USA). Environmental Microbiology, 9(6) 1523-1534.

Melim L.A; Shinglman K.M., Boston P.J., Northup D.E., Spilde M.N..\& Queen J.M. (20o1): Evidence for microbial involvement in pool finger precipitations, Hidden cave, New Mexico. Geomicrobiol. J., 18:311-329.

Melim L.A., Liescheidt R., Northup D.E., Spilde M.N., Boston P.J. \& Queen J.M. (2009): A Biosignature Suite from Cave Pool Precipitates, Cottonwood Cave, New Mexico. Astrobiology, 9(9):907-917.

Mulec J., Zalar P., Zupan Hajna N. \& Rupnik M. (2002): Screening for Culturable Microorganisms from Cave Environments (Slovenia). Acta Carsologica, 31(2):177-187.

Newman D.K.. \& Banfield JF. (2002): Geomicrobiology: molecular-scale interactions underpin biogeochemical systems. Science, 296,:1071-1077.

Northup D.E. \& Lavoie K.H. (2001): Geomicrobiology of caves:a review. Geomicrobiol. I., 18:199-222.

Northup D.E., Reysenbach A.L. \& Pace N.R. (1997): Microorganisms and speleothems. In: CA. Hill, P. Forti (eds) Cave minerals of the world. National Speleological Society, Huntsville, 261-266.

Poulson T.L. \& Lavoie K.H. (20oo): The trophic basis of subsurface ecosystems. In: DC. Wilkens, DC. Culver, WF. Humphreys (eds) Ecosystems of the world 30. Elsevier, Amsterdam, 231-249

Rivadeneyra M.A., Delgado R., Delgado G., Del Moral A., Ferrer M.R. \& Ramos-Cormenza A. (1993): Precipitation of carbonate by Bacillus sp. isolated from saline soils. Geomicrobiol. J., 11: 175-184

Roussel E.G., Cambon Bonavita M.A., Querellou J., Cragg B.A;,Webster G., Prieur D. \& Parkes RJ. (2008): Extending the sub-seafloor biosphere. Science, 320:1046.

Shoji R. \& Folk R.L. (1964): Surface morphology of some limestone types as revealed by electron microscope: Journal of Sedimentary Research, 34, 144-155.

Simon K.S., Benf ield E.F. \& Macko S.A. (2003):. Food web structure and the role of epilthic biof ilms in cave streams. Ecology, 84, 2395-2406.

Srivastava D.K., Singh A.P., Tiwari R.P. \& Jauhri A.K. (2008): Cassiduloids (Echinoidea) from the Siju Formation (late Lutetian-early Bartonian) of the South Garo Hills, Meghalaya, India. Revue de Paléobiologie, Genève, 27 (2): 511-523. 
Whitman W.B., Coleman D.C. \& Wiebe W.J. (1998): Prokaryotes: The unseen majority. Proc. Natl. Acad. Sci. USA, 95:6578-6583

\section{Table 1: Bacterial diversity and species identified in different Indian caves}

\begin{tabular}{|c|c|c|c|c|c|c|}
\hline S.No. & $\begin{array}{l}\text { Name of cave, } \\
\text { / State }\end{array}$ & $\begin{array}{l}\text { Type of } \\
\text { deposit }\end{array}$ & $\begin{array}{l}\text { Cell } \\
\text { enumeration }\end{array}$ & $\begin{array}{l}\text { Bacterial } \\
\text { count cfu/g }\end{array}$ & $\begin{array}{l}\text { Identified species/ } \\
\text { phylotype }\end{array}$ & Reference \\
\hline 1 & $\begin{array}{l}\text { Sahastradhara } \\
\text { /Uttarakhand }\end{array}$ & Stalactite & DAPI & $9 \times 10^{5}$ & $\begin{array}{l}\text { Bacillus thuringiensis } \\
\text { Bacillus pumilis }\end{array}$ & Baskar et al. 2006 \\
\hline 2 & $\begin{array}{l}\text { Sahastradhara } \\
\text { /Uttarakhand }\end{array}$ & Moonmilk & DAPI & $6.3 \times 10^{5}$ & $\begin{array}{l}\text { Bacillus pumilis, B. cereus } \\
\text { B. anthracis B. lentus, } \\
\text { B. circulans B. sphaericus } \\
\text { Actinomycetes }\end{array}$ & Baskar et al. 2014 \\
\hline \multirow[t]{2}{*}{3} & $\begin{array}{l}\text { Borra } \\
\text { /Andhra } \\
\text { Pradesh }\end{array}$ & Biof ilm & SYBR Gold & $6.3 \times 10^{5}$ & $\begin{array}{l}\text { Betaproteobacteria } \\
\text { Leptothrix spp. Alpha, } \\
\text { gamma, deltaproteobacteric }\end{array}$ & Baskar et al. 2012 \\
\hline & & & DAPI & $5.2 \times 10^{5}$ & $\begin{array}{l}\text { Planctomycetes, } \\
\text { Actinobacteria, Acidobacter } \\
\text { Nitrospira, Firmicutes, } \\
\text { Firmicutes, Chloroflexi, } \\
\text { Bacterioidetes }\end{array}$ & \\
\hline 4 & $\begin{array}{l}\text { Krem Mawsmai } \\
\text { /Meghalaya }\end{array}$ & Stalactite & Plate count & $\begin{array}{l}4 \times 10^{3}(\mathrm{NA}) \\
1.2 \times 10^{3}(\mathrm{SA})\end{array}$ & $\begin{array}{l}\text { Bacillus licheniformis, } \\
\text { B. cereus Actinomycetes } \\
\text { Streptomyces }\end{array}$ & Baskar et al. 2009 \\
\hline 5 & $\begin{array}{l}\text { Krem Phyllut } \\
\text { /Meghalaya }\end{array}$ & Stalactite & Plate count & $\begin{array}{l}1.6 \times 10^{2}(\mathrm{TA}) \\
3.2 \times 10^{3} \text { (NA) }\end{array}$ & $\begin{array}{l}\text { Bacillus licheniformis } \\
\text { Bacillus cereus }\end{array}$ & Baskar et al. 2009 \\
\hline 6 & $\begin{array}{l}\text { Krem Phyllut } \\
\text { /Meghalaya }\end{array}$ & $\begin{array}{l}\text { Cave wall } \\
\text { deposit }\end{array}$ & Plate count & $3.5 \times 10^{3}(\mathrm{NA})$ & Bacillus mycoides & Baskar et al. 2009 \\
\hline 7 & $\begin{array}{l}\text { Krem Mawmluh } \\
\text { /Meghalaya }\end{array}$ & Moonmilk & Plate count & $\begin{array}{l}5.6 \times 10^{5}(\mathrm{NA}) \\
6.2 \times 10^{4}(\mathrm{~B} 4) \\
3 \times 10^{2}(\mathrm{SA}) \\
3.5 \times 10^{3}(\mathrm{KIA}) \\
3 \times 10^{3}(\mathrm{MNA}) \\
3.5 \times 10^{2}(\mathrm{TA})\end{array}$ & $\begin{array}{l}\text { Bacillus licheniformis } \\
\text { B. cereus, Actinomycetes } \\
\text { Bacillus pumilis }\end{array}$ & Baskar et al. 2011 \\
\hline 8 & $\begin{array}{l}\text { Krem Mawmluh } \\
\text { Meghalaya }\end{array}$ & $\begin{array}{l}\text { Moonmilk } \\
\text { water }\end{array}$ & Plate count & $6.3 \times 10^{5}$ (NA) & $\begin{array}{l}\text { Micrococcus luteus } \\
\text { Bacillus spp. }\end{array}$ & Baskar et al. 2011 \\
\hline
\end{tabular}

\section{Identification technique: S.No.- 1 to 3: Molecular, DNA sequencing; 4 to 8: Conventional}

NA-Nutrient agar; B4-B4 agar, MNA-Manganese agar, SA-Sulphite agar, KIA-Kliger iron agar, TA-Thiosulphate agar, SYBR-Gold-Cyanin dye nucleic acid stain; DAPI-4',6-diamidino-2-phenylindole fluorescent DNA stain 